\title{
Developing Gifted and Talented Education Program: The Malaysian Experience
}

\author{
Abu Yazid Abu Bakar \\ Faculty of Education, Universiti Kebangsaan Malaysia, Bangi, Malaysia \\ Email:yazid3338@ukm.edu.my
}

How to cite this paper: Bakar, A.Y.A. (2017). Developing Gifted and Talented Education Program: The Malaysian Experience. Creative Education, 8, 1-11. http://dx.doi.org/10.4236/ce.2017.81001

Received: November 9, 2016

Accepted: January 2, 2017

Published: January 6, 2017

Copyright ( 2017 by author and Scientific Research Publishing Inc. This work is licensed under the Creative Commons Attribution International License (CC BY 4.0).

http://creativecommons.org/licenses/by/4.0/

\section{(c) (i) Open Access}

\begin{abstract}
The Malaysian Education Act 550 (1996) outlines six dimensions of national education system namely, the pre-school, elementary, secondary, post-secondary, higher, and special education. Thus, the other paradigms of education; for instance, gifted education, are not considered as mainstreams and do not give considerable attention towards their holistic growth. Even though initiatives to cater for the needs of local population of gifted students or students with high potentials were in existence since the 1960s', such efforts were short-lived due to factors such as lack of instructions, training, leadership, and resources. As such, the direction of Malaysian gifted education programespecially in the setting of school environment-has never been officially established and the effort to design appropriate curriculum for this population of students has never become a national agenda at the ministry of education (MOE) level. This article shares the experience of Pusat PERMATApintar ${ }^{\mathrm{TM}}$ Negara, Universiti Kebangsaan Malaysia (also known as the National Gifted Center) in developing its' own gifted education school program, which officially started in 2011 .
\end{abstract}

\section{Keywords}

Gifted and Talented Education, Gifted and Talented Students, Malaysian Education System

\section{Introduction}

Gifted education has never been considered as one of the Malaysian educational paradigms since the independence of the nation in 1957. The Education Act 550 (1996) specifically spells out the responsibility of the Ministry of Education (MOE) to ensure the holistic development in the paradigms of pre-school, elementary, secondary, post-secondary, higher, and special education. Concomitantly, MOE will only give their support (in terms of curriculum development, 
infrastructure establishment, and human resources preparation) in these six mainstream educational paradigms.

However, the non-existence of gifted education policy in Malaysia (Abu Yazid \& Noriah, 2016; Noriah et al., 2009; Malaysia, 1996) did not mean that the educational provision for gifted and talented learners is being totally discounted in the local system. As a matter of fact, over a period of three decades (1960s through 1990s), MOE has intermittently introduced programs for students with high academic potentials. To illustrate, the introduction of the "Express Class System" in 1962 gave such students the opportunity to accelerate their elementary education. Likewise, the introduction of Level One Assessment System in 1996 was the similar acceleration effort to shorten the elementary education of academically talented students. Nonetheless, all these transformational efforts to develop programs specifically tailored for gifted and talented students were short-lived due to factors such as lack of instructions, training, leadership, and resources. Further exertions to champion the progress of educational provision for local gifted learners were carried out mostly by researchers in public universities and non-govern- mental organizations like the National Association for Gifted Children, Malaysia (NAGCM) and the Malaysian MENSA Society.

Nonetheless, the scenario of Malaysian gifted education has been constantly revolutionized since 2006, with an initial move was set by a recommendation put forward by the Education Planning and Research Department of MOE which emphasized on the necessity to institute a special school for gifted and talented students, or at least the formation of gifted classes in the normal school system, in order to realize the nation's vision to become an industrialized country by the year 2020. The recommendation was later supported with the establishment of local gifted programs in 2009 and 2010, by the names of PERMATApintar ${ }^{\mathrm{TM}}$ and PERMATA Insan. In a recent progress, MOE has launched Malaysia Educational Development Plan 2013-2025 which outlines the nation's educational directions to be realized hopefully in the year of 2025. One of the critical directions in this plan (launched in September 2012) is to constitute a national strategy of education for gifted students. Specifically, the ministry is hoping to formulate an effective gifted education program to be implemented in all schools nationwide, and it should be done in three phases:

1) Phase 1 (2013-2015) - Identifying areas for improvement.

2) Phase 2 (2016-2020) - Piloting new gifted and talented programs.

3) Phase 3 (2021-2025) - Scaling up success.

Following the setting up of two local "laboratory" schools for gifted and talented students namely, the PERMATApintar ${ }^{\mathrm{TM}}$ College at Universiti Kebangsaan Malaysia (in 2011) and PERMATA Insan College at Universiti Sains Islam Malaysia (in 2015), the need to establish a conceptual model for gifted school program in order to support this future direction outlined by MOE has aptly become necessary. Hence, this article is going to discuss the experience of Pusat PERMATApintar ${ }^{\mathrm{TM}}$ Negara, Universiti Kebangsaan Malaysia (also known as the Malaysian National Gifted and Talented Center), in instituting its' school pro- 
gram in terms of comprehensive design and evaluation strategies.

\section{Literature Reviews on Gifted and Talented Education Program}

Shore and Delcourt (1996) suggested that any programs developed for gifted learners must have clear objectives and tailor to their specific/unique needs. Treffinger (1998), on the other hand, proposed that the development of any gifted education programs require comprehensive services based on sound philosophical, theoretical, and empirical supports. Likewise, Purcell and Eckert (2006) recommended that educational programs for the gifted learners should be backed by "new theories, new models, more inclusive definitions of the words gifted and talented, and more sophisticated research techniques that can reveal a great deal about what constitutes best practices in gifted education" (p. 11). Consequently, gifted programs which developed based on strong theoretical and empirical foundations had been found to be effectively benefited the students in terms of their developmental growth (Davis et al., 2011; Ng \& Nicholas, 2010; Goodhew, 2009; Gosfield, 2008; VanTassel-Baska, 2003; Kevin, 2005; Bernal, 2003; Smutny, 2003; Castellano \& Diaz, 2002; Eyre \& Lowe, 2002; Olenchak \& Renzulli, 1989).

Furthermore, Kettler (2011) postulated that three essential elements which are the arrangement of students, curriculum and instruction, and guidance and counseling must exist in any gifted programs within school environment to ensure the effectiveness of such programs. Kettler also posited that the implementation of such programs should also be backed by appropriate funding, infrastructure, technical provision, and sufficient manpower in order to enhance the objective to benefit the gifted students in school setting. In other words, the success of any programs developed for gifted learners at school must be supported by the whole educational authorities and communities including policymakers, administrators, teachers, parents, and school support personnel.

In addition, Reis (cited in Purcell \& Eckert, 2006) suggested that a high-quality gifted education program should be determined by its' derivation of services, comprehensiveness, practicality, consistency, clarity, availability, and continuation/extension/evaluation. She also recommended a comprehensive gifted educational plan known as Comprehensive Program Design (CPD), which among all, must consider the affective needs as well as academic needs, must take into account a broad range of talents to be developed, and should describe curriculum philosophy and address grouping issues. While developing programs for gifted learners at school, Reis also encouraged the program administrators to ask six guiding questions, which will assist the administrators to assess the suitability of the developed programs with the targeted population of students. The questions are as follows:

1) Who will be served?

2) How will the students be identified?

3) What model(s) will be used to develop the program? 
4) What type of services will be provided?

5) Where will such services be provided?

6) When will such services be provided?

\section{PERMATApintar ${ }^{\mathrm{TM}}$ College Education Program}

Taking into considerations all of the abovementioned suggestions, Pusat PERMATApintar ${ }^{\mathrm{TM}}$ Negara had designed a program with clear objectives inspired by the National Education Principle (NEP) to produce well-balanced students in terms of physical, emotional, spiritual, intellectual, and social capabilities. Moreover, the program should encompass worthy identification and curriculum strategies in order to effectively educate the students, while also promoting continuous learning process among the teachers. Hence, the objectives of the program were developed in order to:

1) Create opportunity for local gifted students to develop creative and innovative minds through differentiated learning process

2) Originate a gifted education program which integrates the national and international curriculums with high order learning process

3) Establish smart partnerships with relevant experts in order to set up a holistic model for local gifted education

In general, the PERMATApintar ${ }^{\mathrm{TM}}$ College's program incorporates all principles and requirements put forward by Kettler (2011) and Reis (XX, in Purcell \& Eckert, 2006) in earlier discussion. In other words, the designated program not only stresses on the academic superiority of the students, but also emphasizes on the holistic development of the students as being outlined by the NEP. In order to achieve this objective, the program is designed to:

1) Be based on the Integrated Curriculum Model (ICM).

2) Use multidimensional identification strategies.

3) Integrate ability/achievement grouping, acceleration, and mentoring as curriculum development strategies.

4) Focus on teachers' support and education.

Specifically, the ICM developed by Joyce VanTassel-Baska anchors the holistic development of the program. The model is used due to the fact that it was developed for high ability or gifted and talented students (Gardner et al., 1990; VanTassel-Baska \& Brown, 2007), as well as for mix-ability students (VanTassel-Baska et al., 1998). The model employs selected useful teaching and learning approaches to reinforce three desired dimensions of learning namely: 1) advance content, 2) high-level process and product work, and 3) intra- and interdisciplinary concept development and understanding (VanTassel-Baska, 2008). ICM has been successfully applied in various gifted education settings (VanTassel-Baska et al., 2002; Feng et al., 2005); hence, it is apt to be adapted into PERMATApintar ${ }^{\mathrm{TM}}$ contextual population of gifted students. The program developed based on ICM framework is believed to allow the students to pursue activities at their own pace, to support curiosity and explorative traits of the students by promoting choices, to provide students with opportunity to plan, implement, 
and assess challenging activities, and to offer students opportunity to collaborate with other students who may have similar abilities. Moreover, the implementation of this ICM-based program will create positive change in the students' motivational responses, thinking patterns, and learning growth (VanTassel-Baska et al., 2000; Feng et al., 2005; VanTassel-Baska, 2010). In PERMATApintar ${ }^{\mathrm{TM}}$ College case, the ICM's principles are blended with NEP philosophical traits in order to formulate the foundation model of the proposed gifted program.

Moreover, the program employs a multidimensional approach of students' identification to be selected into the program. Frasier et al. (1995) posit that the identification process of gifted students is very crucial in the development of any gifted programs. In tandem, Davis et al. (2011) postulated that a multidimensional approach which encompasses several identification strategies is the best strategy to select candidates for any particular gifted programs. Similarly, Brown et al. (2005) suggest that an effective gifted students' identification procedure should include multiple criteria for identification and contextual factors, whereas Purcell and Eckert (2006) recommend that a high quality identification method of gifted students should be comprehensive in nature. The identification strategies of PERMATApintar ${ }^{\mathrm{TM}}$ College's gifted education program employed all of these experts' recommendations. In principle, the screening procedure of the program involved a comprehensive evaluation of the students' results in:

1) UKM1 "uncontrolled" online test.

2) UKM2 "controlled" online test.

3) UKM3 competency-based assessment.

This 3-tier multidimensional identification strategy is targeted to tap not only the intellectual capability of the students but also other potentials of the students such as the leadership competency and sporting talents. Thus, the objective to recruit pool of well-rounded gifted students into the program should be achieved by the implementation of this identification procedure.

In terms of curriculum development, the program employed acceleration and mentoring as its' two main implementation methodologies. Research works on acceleration have found its' positive effects on gifted students' academic performance and social/emotional development (Lubinski \& Benbow, 2006; Stanley, 2000; Cornell et al., 1991; Brody et al., 1990; Neihart, 2007; Tiesco, 2003). In particular, the PERMATApintar ${ }^{\mathrm{TM}}$ College's educational program focuses on the options of grade acceleration and content acceleration. Grade acceleration is practiced in a sense that even though the age limit for entrance to the program is 16 years old, students with lower "chronological" age but demonstrate equivalent or superior "mental" age and capabilities will be given opportunity to enroll into the program. In other words, the "asynchronous" development will play a vital role in the program's identification procedure. Content acceleration, on the contrary, takes place in the forms of overall curriculum designed for the program. Specifically, the program offers an accelerated and compacted curriculum with the introduction of fast paced subjects, Advance Placement (AP) courses, and selected first-year university courses. 
Mentoring, on the other hand, acts as a gifted programming strategy which employs a one-to-one role modeling relationship to motivate or inspire the students in their academic and career pursuance (Subotnik et al., 2010; Irving et al., 2003; Bisland, 2001). Other research works in education provide evidences that effective mentoring programs have positive impacts on the protégé/mentee learning abilities, leadership skills, self-esteem, and career pathways (Noriah, 2012; Chan, 2000; Torrance, 1980). In PERMATApintar ${ }^{\mathrm{TM}}$ College, the mentoring program focuses on the development of the students' capability to carry out academic research, whereby each of them will be paired with a particular university professor to enable them to learn and be guided in research area of their interests. In other words, each student enrolls in this program has the opportunity to work closely with academic scholars in his/her school years, which in turn will develop all their potentials as being discussed.

Another essential element of the program is the provision of teacher support and education. In any particular educational programs, the element of teachers' professional development is considered detrimental to ensure the success of the program. Little (1993) posited that professional development is one of the key principles to educational reform, whereas VanTassel-Baska and Brown (2007) perceived it as a support mechanism to improve the teachers' teaching skills. Other researchers also believed that professional development is a continuous process that is needed to enhance the teachers' practical knowledge (Campbell, 2008; Borko, 2004; Garet et al., 2001; Jan et al., 2001). In order to achieve all of the abovementioned teachers' professional development purposes, PERMATApintar $^{\mathrm{TM}}$ College's school program provides a continuous two year in-house training, in which relevant experts (locally and internationally) are consulted and engaged in order to coach the teachers particularly in the aspects of teaching pedagogy, evaluation/assessment competency, psycho-socio-emotional support system, and ability to conduct research. At the end of the two-years training program, a group of master teachers will set up a training team, in order to produce future instructors for the program.

\section{PERMATApintar ${ }^{\mathrm{TM}}$ College Education Program's Evaluation Strategies}

VanTassel-Baska and Brown (2007) indicated that "the use of formative and summative accountability measures to inform teachers and administrators of students' progress throughout the implementation cycle" (pg. 352) is a critical support element in implementing new curriculum in any given programs tailored for gifted population of students. Likewise, Gallagher (2006) indicated that both formative and summative assessments were equally essential in producing comprehensive evaluation for gifted programming, whereas Gibb and Simpson (2004) posited that effective assessment (both formative and summative) supports learning among students and creates positive intrinsic motivation for students to ascend in their learning passage. Taken these experts' opinions into consideration, the PERMATApintar ${ }^{\mathrm{TM}}$ College's educational program utilizes 
both formative and summative measures as strategies to assess the students' overall performance. Specifically, the formative assessment is done in terms of tests (pre, post, and oral) administration, evaluative reports, and other workloads (i.e. assignments, presentations, etc.). On the other hand, the summative assessment of the students' performance will take place in the form of examinations' scores that the students sit for (mid-term, final, national).

As for the overall evaluation, the integrated approach is utilized to assess the program's effectiveness. Rimm (1982) recommended that a framework for the evaluation and monitoring of a gifted program should encompass components of input (resources), process (activities), and outcome (objectives). In short, Rimm's model proposed that any decisions to be made by the decision makers on a particular gifted program should consider overall aspects of the program implementation, and also take into account feedbacks from all stakeholders (students, teachers, parents, personnel) of the program. Adapting this suggestion, the $360^{\circ}$ PERMATApintar ${ }^{\mathrm{TM}}$ College's school program evaluation is designed to gather information from all stakeholders through:

1) The analysis of all administered program tests (pre, post, etc.) in order to assess the students' achievement.

2) The administration of surveys on stakeholders' (students, parents teachers, administrators) satisfaction on the program's implementation.

3) The conduct of interviews (focus group and in-depth interview) on all stakeholders to gather their views on the program's strengths and weaknesses.

These holistic and comprehensive evaluation strategies hopefully will supply the PERMATApintar ${ }^{\mathrm{TM}}$ College administration with sufficient information to assess the program effectiveness after the first five years of its implementation.

\section{Discussion and Conclusion}

When the Malaysian gifted and talented education program was constructed in 2009-2010, the results and responses from general public over its' implementation are expected to be positive due to two pinpointing factors. First, the growing interest of gifted and talented education in local scene for the past five years has been overwhelming. The launching of Malaysia Educational Development Plan 2013-2025 in 2012 had increased the curiosity of public community, especially parents, to learn more on this educational paradigm. Since there is no such program to be referred as a local gifted education program just yet, the inception of PERMATApintar ${ }^{\mathrm{TM}}$ College is considered timely to filling in the gap. Second, the proposed program which is developed based on the ICM framework is deemed to be successful due to several concrete findings of previous research works. For instance, Henderson (2004) suggested that the usage of ICM improves students' performance, while VanTassel-Baska (2005) revealed that ICM elevates students' motivation to learn. Moreover, ICM is believed to create positive change in attitudes among teachers (VanTassel-Baska et al., 2000). Inevitably, ICM has been applied in a variety of educational settings and among gifted populationwhereby the application of acceleration and mentoring as curriculum strategies- 
with huge success. To illustrate, a number of studies found positive effects of acceleration on gifted students in terms of academic performance, opportunity for early college admission, and socio-emotional development (Rinn, 2007; Lubinski \& Benbow, 2006; Stanley, 2000; Cornell et al., 1991; Brulles et al., 2010). On a similar note, studies by Noriah (2012), Irving et al. (2003) and Chan (2000) revealed that mentoring can become an effective gifted programming strategy-to facilitate the students' academic achievement, career determination, and psychosocio-emotional growth-provided that critical factors mentioned below were taken into consideration:

1) Objectives of the mentoring program are clarified to both mentor and protégé/mentee.

2) The matching process of mentor and protégé/mentee is meticulously done.

3) Training of roles and responsibilities is conducted for both mentor and protégé/mentee.

4) The willingness to give full commitment by all involved parties.

5) The existence of systematic monitoring process.

Concomitantly, PERMATApintar ${ }^{\mathrm{TM}}$ College education program has shown several success stories that should justify its' establishment objectives in 2011. For instance, the Sijil Pelajaran Malaysia (SPM) result of its' first three cohortsplaced at nation's top five lists for three consecutive years-has allowed them to be given the status of semi government-assisted school after four years of operation. In addition, more than 100 of its' exceptionally gifted and talented students have been furthering their studies overseas (at top universities in United States of America and United Kingdom) at the age of 16 years old, without having to go through SPM. Their placement at these top universities has proven that Malaysia does have its fair share of gifted and talented students' population. Given the right environment and support, they will shine and able to optimize their potentials to the fullest. The success in executing the program in PERMATApintar $^{\mathrm{TM}}$ College, Universiti Kebangsaan Malaysia would contribute to the setting up of referral framework for gifted and talented education program to be implemented in the local educational scene. Therefore, the program could become as a local benchmark for MOE to establish relevant policies in order to comprehend the goal outlined by the Malaysian Educational Development Plan 2013-2025, as discussed earlier.

In a nutshell, the Pusat PERMATApintar ${ }^{\mathrm{TM}}$ Negara's experience in building its' own gifted and talented school program is really a dedicated journey of setting up foundation of gifted and talented education paradigm in a local scene. It is a learning experience which hopefully will uplift the status of Malaysian gifted and talented education to the same level as other developed nations. The success stories and performance achieved by PERMATApintar ${ }^{\mathrm{TM}}$ College have received numerous recognitions locally and internationally, and all these have become a benchmark to the worthy standard of the program.

\section{References}

Abu Yazid, A. B., \& Noriah, M. I. (2016). Pendidikan Pintar dan Berbakat di Malaysia. 
Bangi: Penerbit UKM.

Bernal, E. M. (2003). To No Longer Educate the Gifted: Programming for Gifted Students beyond the Era of Inclusionism. Gifted Child Quarterly, 47, 183-191. https://doi.org/10.1177/001698620304700302

Bisland, A. (2001). Mentoring: An Educational Alternative for Gifted Students. Gifted Child Today, 24, 22-25.

Borko, H. (2004). Professional Development and Teacher Learning: Mapping the Terrain. Educational Researcher, 33, 3-15. https://doi.org/10.3102/0013189X033008003

Brody, L. E., Assouline, S. G., \& Stanley, J. C. (1990). Five Years of Early Entrants: Predicting Successful Achievement in College. Gifted Child Quarterly, 34, 138-142. https://doi.org/10.1177/001698629003400402

Brown, S. W., Renzulli, J. S., Gubbins, E. J., Siegle, D., Zang, W., \& Chen, C.-H. (2005). Assumptions Underlying the Identification of Gifted and Talented Students. Gifted Child Quarterly, 49, 68-79. https://doi.org/10.1177/001698620504900107

Brulles, D., Saunders, R., \& Cohn, S. J. (2010). Improving Performance for Gifted Students in a Cluster Grouping Model. Journal for the Education of the Gifted, 34, 327352.

Campbell, E. (2008). The Ethics of Teaching as a Moral Profession. Curriculum Inquiry, 38, 357-385. https://doi.org/10.1111/j.1467-873X.2008.00414.X

Castellano, J. A., \& Diaz, E. I. (2002). Reaching New Horizons: Gifted and Talented Education for Culturally and Linguistically Diverse Students. Boston, MA: Allyn \& Bacon.

Chan, D. W. (2000). The Development of Mentorship Programs at the Chinese University of Hong Kong. Roeper Review, 23, 85-88.

https://doi.org/10.1080/02783190009554072

Cornell, D. G., Callahan, C. M., \& Lloyd, B. H. (1991). Personality Growth of Female Early College Entrants: A Controlled, Prospective Study. Gifted Child Quarterly, 35, 135-143.

Davis, G. A., Rimm, S. B., \& Siegle, D. (2011). Education of the Gifted and Talented (6th ed.). Boston, MA: Pearson.

Eyre, D., \& Lowe, H. (2002). Curriculum Provision for the Gifted and Talented in the Secondary School. New York, NY: David Fulton Publishers.

Feng, A., VanTassel-Baska, J., Quek, C., Bai, W., \& O’ Neill, B. (2005). A Longitudinal Assessment of Gifted Students' Learning Using the Integrated Curriculum Model (ICM): Impacts and Perceptions of the William and Mary Language Arts and Science Curriculum. Roeper Review, 27, 78-83. https://doi.org/10.1080/02783190509554294

Frasier, M. M., Garcia, J. H., \& Passow, A. H. (1995). A Review of Assessment Issues in Gifted Education and Their Implications for Identifying Gifted Minority Students. Storrs, CT: The National Research Center on the Gifted and Talented, The University of Connecticut.

Gallagher, J. J. (2006). How to Shoot Oneself in the Foot with Program Evaluation. Roeper Review, 28, 122-124. https://doi.org/10.1080/02783190609554350

Gardner, B., Haugland, S., Spezia, M., \& Boissoneau, R. (1990). Integrated Learning: A Viable Alternative to Gifted Programs. Early Child Development and Care, 63, 107-118. https://doi.org/10.1080/0300443900630114

Garet, M. S., Porter, A. C., Desimone, L., Birman, B. F., \& Yoon, K. S. (2001). What Makes Professional Development Effective? Results from a National Sample of Teachers. American Education Research Journal, 38, 915-945.

https://doi.org/10.3102/00028312038004915 
Gibb, G., \& Simpson, C. (2004). Conditions under Which Assessment Supports Students Learning. Learning and Teaching in Higher Education, 1, 3-31.

Goodhew, G. (2009). Meeting the Needs of Gifted and Talented Learners. Minneapolis, MN: Free Spirit Pub. Inc.

Gosfield, M. W. (2008). Expert Approaches to Support Gifted Learners. Minneapolis, MN: Free Spirit Pub. Inc.

Henderson, L. (2004). Unleashing Talent: An Examination of VanTassel-Baska's Integrated Curriculum Model. Post-Script, 5, 55-73.

Irving, S. E., Moore, D. W., \& Hamilton, R. J. (2003). Mentoring High Ability Students. Education + Training, 45, 100-109. https://doi.org/10.1108/00400910310464071

Jan, H. V., Driel, J. H. V., Beijaard, D, \& Verloop, N. (2001). Professional Development and Reform in Science Education: The Role of Teachers' Practical Knowledge. Journal of Research in Science Teaching, 38, 137-158. https://doi.org/10.1002/1098-2736(200102)38:2<137::AID-TEA1001>3.0.CO;2-U

Kettler, T. (2011). Grouping and Instructions for Gifted Students. Gifted Child Today, 34, 62-63.

Kevin, B. (2005). Using Public Relation Strategies to Advocate for Gifted Programming in Your School. Gifted Child Today, 28, 32-37.

Little, J. W. (1993). Teachers' Professional Development in a Climate of Educational Reform. Educational Evaluation and Policy Analysis, 15, 129-151. https://doi.org/10.3102/01623737015002129

Lubinski, D., \& Benbow, C. P. (2006). Study of Mathematically Precocious Youth after 35 Years: Uncovering Antecedents for the Development of Math-Science Expertise. Perspectives on Psychological Science, 1, 316-345.

https://doi.org/10.1111/j.1745-6916.2006.00019.x

Malaysia (1996). Education Act 550.

Neihart, M. (2007). The Socioaffective Impact of Acceleration and Ability Grouping Recommendations for Best Practice. Gifted Child Quarterly, 51, 330-341. https://doi.org/10.1177/0016986207306319

Ng, W., \& Nicholas, H. (2010). A Progressive Pedagogy for Online Learning with HighAbility Secondary School Students: A Case Study. Gifted Child Quarterly, 54, 239-251. https://doi.org/10.1177/0016986209355973

Noriah, M. I. (2012). Mentoring for Research Activities among Gifted and Talented Students. In International Association of Prosecutors 2012 Strategic Business Plan. Bangi: PusatPERMATApintar ${ }^{\mathrm{TM}}$ Negara.

Noriah, M. I., Rosadah, A. M., \& Siti, R. A. (2009). Sejarah dan konsep PERMATApintar. In M. I. Noriah, A. M. Rosadah, \& F. M. Y. Siti (Eds.), PERMATApintar: Pengalaman $U K M$ (pp. 1-18). Bangi: Pusat PERMATApintar ${ }^{\mathrm{TN}}$ Negara. $^{-}$

Olenchak, F. R., \& Renzulli, J. S. (1989). The Effectiveness of the Schoolwide Enrichment Model on Selected Aspects of Elementary School Change. Gifted Child Quarterly, 33, 36-46. https://doi.org/10.1177/001698628903300106

Purcell, J. H., \& Eckert, R. D. (2006). Designing Services and Programs for High-Ability Learners: A Guidebook for Gifted Education. Thousand Oaks, CA: Corwin Press. https://doi.org/10.4135/9781483329307

Rimm, S. (1982). Evaluation of Gifted Programs-As Easy as ABC. Roeper Review, 5, 8-11. https://doi.org/10.1080/02783198209552647

Rinn, A. N. (2007). Effects of Programmatic Selectivity on the Academic Achievement, 
Academic Self-Concepts, and Aspirations of Gifted College Students. Gifted Child Quarterly, 51, 232-245. https://doi.org/10.1177/0016986207302718

Shore, B. M., \& Delcourt, M. A. B. (1996). Effective Curricular and Program Practices in Gifted Education and the Interface with General Education. Journal for the Education of the Gifted, 20, 138-154.

Smutny, J. F. (2003). Designing and Developing Programs for Gifted Students. Thousand Oaks, CA: SAGE Publications.

Stanley, J. C. (2000). Helping Students Learn Only What They Don't Already Know. Psychology, Public Policy and Law, 6, 216-222. https://doi.org/10.1037/1076-8971.6.1.216

Subotnik, R. F., Edmiston, A. M., Cook, L., \& Ross, M. D. (2010). Mentoring for Talent Development, Creativity, Social Skills, and Insider Knowledge: The APA Catalyst Program. Journal of Advance Academics, 21, 714-739. https://doi.org/10.1177/1932202X1002100406

Tiesco, C. L. (2003). Ability Grouping Is Not Just Tracking Anymore. Roeper Review, 26, 29-36. https://doi.org/10.1080/02783190309554236

Torrance, E. P. (1980). Creativity and Style of Learning and Thinking Characteristics of Adaptors and Innovators. Creative Child \& Adult Quarterly, 5, 80-85.

Treffinger, D. J. (1998). From Gifted Education to Programming for Talent Development. Phi Delta Kappan, 79, 752-755.

VanTassel-Baska, J. (2003). Curriculum Planning and Instructional Design for Gifted Learners. Denver, CO: Love Publishing.

VanTassel-Baska, J. (2005). Acceleration: Strategies for Teaching Gifted Learners. Waco, TX: Prufrock Press, Inc.

VanTassel-Baska, J. (2008). What Works in Curriculum for the Gifted. In The 10th AsiaPacific Conference on the Gifted.

VanTassel-Baska, J. (2010). Study of Life Themes in Charlotte Bronte and Virginia Woolf. Roeper Review, 18, 14-19. https://doi.org/10.1080/02783199509553690

VanTassel-Baska, J., \& Brown, E. F. (2007). Towards Best Practice: An Analysis of the Efficacy of Curriculum Models in Gifted Education. Gifted Child Quarterly, 51, 342-358. https://doi.org/10.1177/0016986207306323

VanTassel-Baska, J., Avery, L. D., Little, C. A., \& Hughes, C. E. (2000). An Evaluation of the Implementation: The Impact of the William and Mary Units on Schools. Journal for the Education of the Gifted, 23, 244-272.

VanTassel-Baska, J., Bass, G. M., Reis, R. R., Poland, D. L., \& Avery, L. D. (1998). A National Study of Science Curriculum Effectiveness with High Ability Students. Gifted Child Quarterly, 42, 200-211. https://doi.org/10.1177/001698629804200404

VanTassel-Baska, J., Zuo, L., Avery, L. D., \& Little, C. A. (2002). A Curriculum Study of Gifted Student Learning in the Language Arts. Gifted Child Quarterly, 46, 30-44.

https://doi.org/10.1177/001698620204600104 
Submit or recommend next manuscript to SCIRP and we will provide best service for you:

Accepting pre-submission inquiries through Email, Facebook, LinkedIn, Twitter, etc. A wide selection of journals (inclusive of 9 subjects, more than 200 journals)

Providing 24-hour high-quality service

User-friendly online submission system

Fair and swift peer-review system

Efficient typesetting and proofreading procedure

Display of the result of downloads and visits, as well as the number of cited articles Maximum dissemination of your research work

Submit your manuscript at: http://papersubmission.scirp.org/

Or contact ce@scirp.org 